A

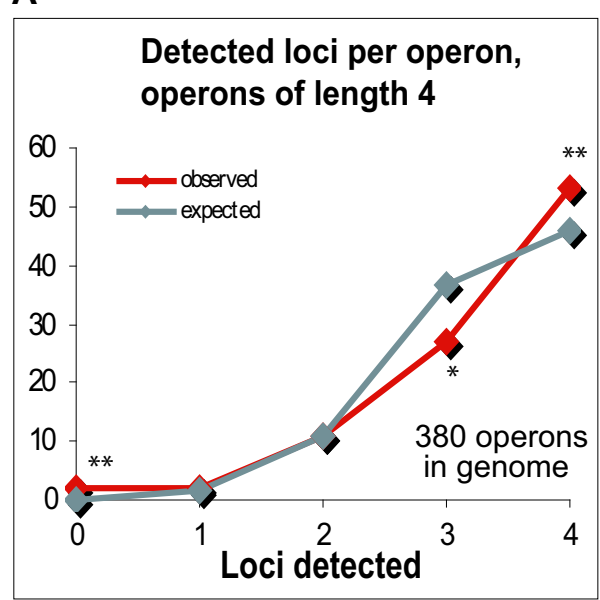

Deviation from expectation: ${ }^{*} p<0.05$
B

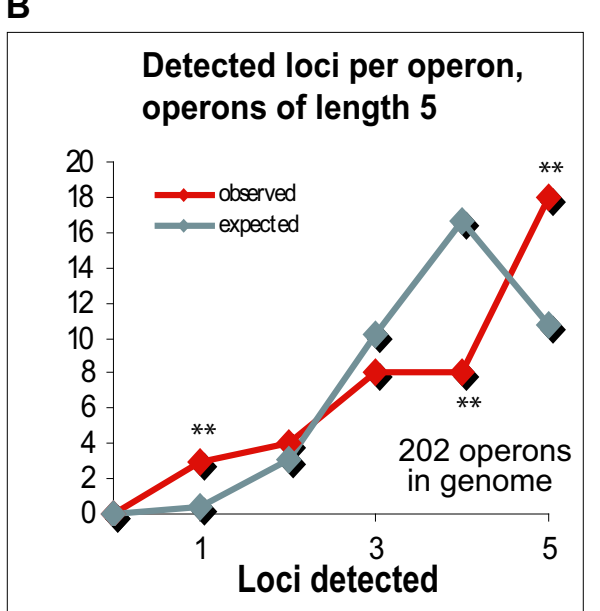

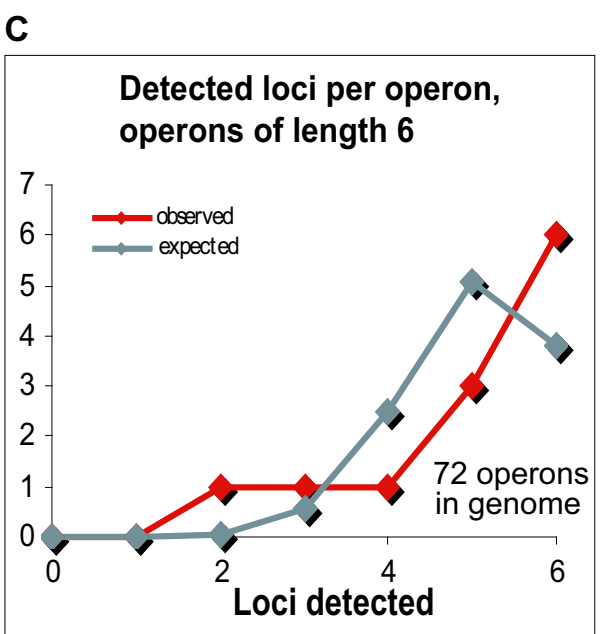

${ }^{* *} p<0.01$

\title{
Figure S2
}

Coordinated expression of operon genes. The number of detected loci per operon deviates from what would be expected under simple independence, as shown exemplary for operons of lengths 4 - 6 (A-C). A higher fraction of operons than expected is either fully expressed (all proteins detected) or hardly expressed at all (none or only few proteins detected). 